\section{Revista de la \\ Universidad del Thulia}

Fundada en 1947 por el Dr. Jesúns Enrique Lossada

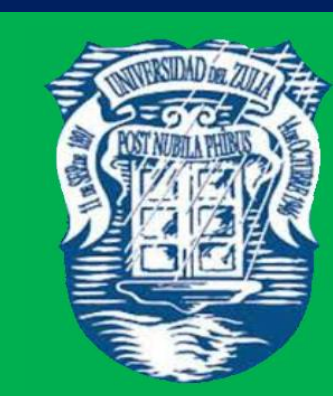

Ciencias del

Algreo

Ingemieria

y Teemología

\section{Aกัต 11 No 29}

Enero - Abril 2021

Tercera Época

Maracaibo-Venezuela 
REVISTA DE LA UNIVERSIDAD DEL ZULIA. $3^{a}$ época. Año $11 \mathrm{~N}^{\circ}$ 29, 2020

Vladimir Nikolaevich Aniskin, et al./// Teaching potential of integrated learning... 328-336

\title{
Teaching potential of integrated learning technologies Smart, Stem and Steam
}

\author{
Vladimir Nikolaevich Aniskin * \\ Aleksandr A. Korostelev ** \\ Busygina Alla Lvovna * \\ Anatoly V. Kurochkin *** \\ Tatyana G. Sobakina ****
}

\begin{abstract}
At the current stage of digitization of the Russian economy, educational institutions urgently need new, more advanced and effective training technologies that help improve the quality of training of highly competent and competitive specialists who comply with the social order of society digital. These technologies should promote the introduction of robotic and cyber-physical systems in the training of future specialists. The article shows that SMART, STEM and STEAM integrated learning technologies that encompass the theoretical and practical components of educational programs with the help of special technological equipment: robotic complexes, virtual learning tools and cyber systems, can be used as technologies in the digital education. It is proven that the practical application of mathematical, physical, engineering and technological knowledge, modeling and design of robotic cybernetic devices and others, allow us to more effectively solve the tasks of the competition-oriented educational paradigm, create additional conditions for the development and realization of the personal potential of the students. The integrative didactic potential of SMART, STEM and STEAM technologies is determined, ensuring the achievement of the synergistic effect in the educational process and increasing the productivity of education subjects through the combination of the individual means of the technologies studied in a single system. The advantages of digital education are analyzed, which are optimized using the integrative teaching potential of SMART, STEM and STEAM technologies. Based on the characteristics of the integrative didactic potential of SMART, STEM and STEAM technologies, it is concluded that they are promising in the era of the digitization of Russian education and viable to use them in order to maintain the effectiveness of the educational process.
\end{abstract}

KEY WORDS: digitization of education; SMART, STEM and STEAM integrated learning technologies; technology; didactic properties and functions; integrative teaching potential; synergistic effect.

* Samara State University of Social Sciences and Education, Russia.

**Togliatti State University, Russia, azshar2017@mail.ru

${ }^{* * *}$ Kazan Federal University, Russia.

${ }^{* * * *}$ North-Eastern Federal University, Russia.

Recibido: 06/02/2020

Aceptado: 19/03/2020 
REVISTA DE LA UNIVERSIDAD DEL ZULIA. $3^{a}$ época. Año $11 \mathrm{~N}^{\circ}$ 29, 2020

Vladimir Nikolaevich Aniskin, et al./// Teaching potential of integrated learning... 328-336

\section{Potencial didáctico de las tecnologías de aprendizaje integradas Smart, Stem y Steam}

RESUMEN

En la etapa actual de la digitalización de la economía rusa, las instituciones educativas necesitan urgentemente tecnologías de capacitación nuevas, más avanzadas y efectivas que ayuden a mejorar la calidad de la capacitación de especialistas altamente competentes y competitivos que cumplan con el orden social de la sociedad digital. Estas tecnologías deberían promover la introducción de sistemas robóticos y ciberfísicos en la formación de futuros especialistas. El artículo muestra que las tecnologías de aprendizaje integradas SMART, STEM y STEAM que abarcan los componentes teóricos y prácticos de los programas educativos con la ayuda de equipos tecnológicos especiales: complejos robóticos, herramientas virtuales de aprendizaje y sistemas cibernéticos, pueden utilizarse como tecnologías en la educación digital. Está comprobado que la aplicación práctica de conocimientos matemáticos, físicos, de ingeniería y tecnológicos, el modelado y el diseño de dispositivos cibernéticos robóticos y otros, nos permiten resolver de manera más efectiva las tareas del paradigma educativo orientado a la competencia, crea condiciones adicionales para el desarrollo y la realización del potencial personal de los estudiantes. Se determina el potencial didáctico integrador de las tecnologías SMART, STEM y STEAM, asegurando el logro del efecto sinérgico en el proceso educativo y aumentando la productividad de los sujetos de educación a través de la combinación de los medios individuales de las tecnologías estudiadas en un solo sistema. Se analizan las ventajas de la educación digital, que se optimizan utilizando el potencial didáctico integrador de las tecnologías SMART, STEM y STEAM. Sobre la base de las características del potencial didáctico integrador de las tecnologías SMART, STEM y STEAM, se concluye que son prometedoras en la era de la digitalización de la educación rusa y viables para utilizarlas a fin de mantener la eficacia del proceso educativo.

PALABRAS CLAVE: digitalización de la educación; tecnologías de aprendizaje integradas SMART, STEM y STEAM; tecnología; propiedades y funciones didácticas; potencial didáctico integrador; efecto sinérgico.

Introduction

The current stage of development of scientific and technological progress has led to the urgency of digitalization of the Russian education system, which, in turn, has determined the need for educational institutions at all levels in new, more advanced and 
effective technologies for training and education. Among the basic requirements for them, one can single out the need to comply with the integration requirements in the study and research of material and virtual objects, processes, phenomena, i.e. the presence of such didactic and research properties and functions that can ensure the implementation of the didactic potential of digital electronic communication tools and education systems. In addition, new digital educational technologies should fully promote and effectively accompany the introduction of robotic and cyberphysical systems, 3D-design systems, engineering, artificial intelligence in the training of future specialists.

\section{Methodology}

In modern pedagogy, the concept of "SMART technology" (smart or intelligent technology) has been used relatively recently, although in other sciences, primarily technical and economic, it has been used for more than forty years. There is no doubt that the main reasons that generated the inclusion of this term in the pedagogical thesaurus should be considered the achievements of scientific and technological progress in general and the development of digital means of computer science and information and communication technologies, in particular. A clear confirmation of the above can serve as the results of the work of such researchers as: N.V. Dneprovskaya, E.A. Yankovskaya (2015); Mahotin, 2018; H. Nakashima, H. Aghajan, J.C. Augusto, 2009; A.V. Zavrazhin (2015) and others.

In addition to this, along with widely known and already familiar in the field of education, intelligent SMART technologies such as: the Internet and local educational networks, interactive whiteboards SMART Board, tablets and other digital tools and devices, recently in practice educational organizations are increasingly introducing STEM- (science, technology, engineering and mathematics - science, technology, engineering, mathematics) and STEAM technology (science, technology, engineering, art and mathematics - science, technology, engineering, art being, mathematics). 
REVISTA DE LA UNIVERSIDAD DEL ZULIA. $3^{a}$ época. Año $11 \mathrm{~N}^{\circ}$ 29, 2020

Vladimir Nikolaevich Aniskin, et al./// Teaching potential of integrated learning... 328-336

\section{Results}

The digitalization of the Russian education system is rapidly gaining momentum, in accordance with the Digital Economy of the Russian Federation program until 2024, approved by order of the Government of the Russian Federation in July 2017, one of the goals of which is to improve the education system to provide the digital economy with competent personnel (Timofeev et al, 2019). Work to achieve this goal should contribute to improving the quality of training in educational institutions of highly qualified and competitive specialists who meet the social order of society and are able to effectively participate in the development of the digital economy.

It is known that in the narrow sense of digitalization, it represents the replacement of analog systems for collecting and processing information with technological systems that can generate, transmit and process a digital signal about their status, and in a broad sense it can be considered as: "the process of transferring functions and activities into a digital environment (business processes) previously performed by people and organizations "(Idrisov et al., 2018). Therefore, we can conclude about the advantages and benefits of digitalization in the economy, industry, energy, other areas of human activity and, accordingly, about the goals and objectives that educational institutions now face in training personnel for the digital economy. However, the digitalization of education, as noted by I.V. Dubrovina (2018), F.F. Sharipov, S.A., (2017); Akhmetzhanova, A.V. Yuryev (2018); E.I. Klemasheva (2018) gives rise to an additional, and very significant, problem of organizing personal education on the basis of the formation and development of the level of its general cultural training through SMART technologies, rapidly penetrating into all areas of activity, gaining the status of basic ones in them and becoming the basis of the modern electronic information and educational environment, "how physical infrastructure that allows the surrounding intellect to function" (Nakashima et al, 2009) as part of cybernetic interaction in human-smart systems (intellectual) environment" (Mahotin, 2018). Obviously, according to V.A. Krasilnikova (2012); O.M. Gyshchina (2015); E.N. Bobyshev (2015); A.V. Matveeva, E.A. Krotova (2017); M. S. Ivinskaya (2017) which, along with the noted problem, the intensification of the use of new digital educational technologies will contribute to exacerbating the negatives of digitalization of the 
REVISTA DE LA UNIVERSIDAD DEL ZULIA. $3^{a}$ época. Año $11 \mathrm{~N}^{\circ}$ 29, 2020

Vladimir Nikolaevich Aniskin, et al.// Teaching potential of integrated learning... 328-336

processes of education and personal education, such as: loss of oral and written verbal communication skills; screen, gamified and social network smartphone addiction; hypertrophied virtualization of socially significant skills and competencies; visual impairment, decreased motor activity of students, etc. These and some other problems give us reason to believe that at the stage of digitalization of the educational process, STEM and STEAM technologies of mixed, integrated learning can become very relevant and practical in practice. combine theoretical and practical components of educational programs through special technological equipment, including the so-called SMART systems and environments, robotics FIR systems, virtual learning tools and cybernetic systems.

Intensification of practical application of mathematical, physical, engineering and technological knowledge, achievements of natural sciences and advanced scientific methods, modeling and designing of our own robots and other devices allows us to better solve the tasks of a competence-oriented education paradigm, creates additional conditions for the development and realization of students' personal potential, motivation for the constant expansion of their horizons, stimulating interest in learning English as the main on the language of modern science (Averin \& Marko, 2017; HabibMireles et al., 2015).

In STEAM technology, to the first four names of scientific and subject areas that are especially significant in the development of modern technologies for the training of specialists especially in demand by society and employers, a creative direction has also been added (art - art). From the point of view of the topic of our study, this supplement can be considered as a holistic component that allows productively and diffusely integrate learning outcomes in mathematics, natural science subject areas, information technology, engineering disciplines, and robotics. And engineering, in STEAM technology is positioned as engineering art (Aniskin et al., 2016).

By the didactic potential of STEM and STEAM technologies, we mean those educational and, first of all, educational opportunities that are determined by the combination of didactic properties and functions of their implementation tools and can be used to optimize and individualize the quality training of future digital specialists, its integration and differentiation according to an algorithm defined by the 
requirements of federal state educational standards (Prigogine, 2003). The didactic properties of the means for implementing STEM and STEAM technologies are their design capabilities used to solve the problems of the educational process, and the didactic functions are their external manifestation in this process. It is worth noting that, in addition to traditional computer hardware and software, the main tool base for the successful functioning of STEM and STEAM technologies includes such a top Atriad of SMART systems and environments, such as iPhone, iPad and Android, which have proved their effectiveness not only in the digital economy, but also in engineering, management, financial and economic education (Glukhov, Vasetskaya, 2017).

According to D.A. Mahotina, the further development of SMART-technologies determines not only their leading role in the development and rapid progress of "smart" environments and "smart" production industries, but also ensures intensive, almost limitless, penetration into all spheres of human activity, including education. The organization and management of constantly and continuously changing educational systems based on the introduction of new and latest promising digital computer ICTs and electronic educational resources, including STEM and STEAM education technologies, makes it possible to efficiently and productively solve the problems of the educational process at a higher intellectual level and achieve the required goals in the quality policy of upcoming digital education (Mahotin, 2018). In our opinion, it is precisely these opportunities that determine one of the most important components of the integrative didactic potential of SMART, STEM, and STEAM technologies in solving the problems of digitalization of Russian education.

The noted possibility determines the next, very significant component of the integrative didactic potential of SMART-, STEM- and STEAM-technologies.

Also, the advantages of digital SMART education (Dneprovskaya \& Yankovskaya, 2015; Mahotin, 2018) can be included in the structure of the integrative didactic potential of SMART, STEM, and STEAM technologies:

- thematic interdisciplinary and design training based on the integration of natural sciences, engineering, information technology and mathematics;

- intensification and increase in the share of the practical component of the educational process in order to demonstrate to students the benefits of operational 
implementation and application of modern scientific and technical results and achievements in real life;

- the possibility of studying specific projects and creating prototypes of a real product;

the formation and development of skills and critical thinking and problem solving in the processes of modeling, 3D-designing and prototyping of the created educational and research product with its subsequent testing to achieve the goal;

- ensuring active team communications by creating a free and comfortable atmosphere for students to discuss their own opinions, present personal results and achievements that contribute to better learning of lesson materials or extracurricular activities;

- motivation and development of students' interest in natural science and engineering technical disciplines based on the game elements of SMART-, STEM-and STEAM-classes;

phased SMART-, STEM- and STEAM-training, corresponding to the consistency of the project approach as the basis for creativity and innovativeness of the educational process;

- organization of independent work of students to operate with the knowledge gained in training sessions to strengthen them on the principle of supplementing STEM and STEAM programs with gaming, entertainment and cognitive experiments to the main educational programs (Budnyk, O. 2018).

Applicable to the digitalization of higher education, from the above components of the integrative didactic potential of SMART, STEM, and STEAM technologies, one can single out such most advantageous advantages as the possibility of activating the educational process by creating digital content to individualize the educational activities of students through the formation and development of critical thinking abilities, effective ways and methods of team and independent work. Interpreting the characteristics of STEM-technologies A.I. Prigozhin, one should also note their combinatorial innovative potential, which can provide organizational, managerial and pedagogical innovations that are beneficial for higher education (Budnyk, 2018). 
REVISTA DE LA UNIVERSIDAD DEL ZULIA. $3^{a}$ época. Año $11 \mathrm{~N}^{\circ}$ 29, 2020

Vladimir Nikolaevich Aniskin, et al./// Teaching potential of integrated learning... 328-336

\section{Conclusions}

In general, from the above components of the integrative didactic potential of SMART-, STEM- and STEAM-technologies, we can conclude that they are promising in the era of digitalization of Russian education and the advisability of applying to maintain the effectiveness of the educational process, adapting the current electronic information and educational environments to new conditions, ensuring the productive compatibility of educational and educational work in the digital educational environment.

\section{References}

Akhmetzhanova G.V., Yuryev A.V. (2018). Digital technologies in education. Baltic Humanitarian Journal. T. 7. No. 3 (24). S. 334-336.

Aniskin V.N., Gorbatov S.V., Dobudko A.V., Dobudko T.V. (2016). Monitoring and evaluation in the new electronic information educational environment of high school. Azimuth of Scientific Research: Pedagogy and Psychology. T. 5. No. 4 (17). S. 36-40.

Averin, S.A., \& Markova, V.A. (2017). Stem-technologies in education: fashion or reality?. In The child in the modern educational space of a metropolis (pp. 193-202).

Bobyshev E.N. (2015). About mechanisms of implementation of strategy of progress information society. Azimuth of Scientific Research: Economics and Administration. No. 1 (10). S. 21-23.

Budnyk, O. (2018). Theoretical principles of using STEAM-technologies in the preparation of the teacher of the New Ukrainian School. Journal of Vasyl Stefanyk Precarpathian National University, 5 (1), 23-30.

Dneprovskaya, N.V., \& Yankovskaya, E.A. (2015). Key concepts for smart education concepts 1. Russia: trends and development prospects, (10-2).

Dubrovina, I.V. (2018). Psychological problems of raising children and schoolchildren in the information society. National Psychological Journal, (1 (29)).

Glukhov, V.V., \& Vasetskaya, N.O. (2017). Smart education as a tool to improve the quality of vocational training. Questions of teaching methods in high school, 6 (21).

Gyshchina O.M. (2015). Competence approach in creation of the information and educational environment of knowledge with using of electronic resources. Baltic Humanitarian Journal. 2015. No. 2 (11). S. 49-52. 
REVISTA DE LA UNIVERSIDAD DEL ZULIA. $3^{a}$ época. Año $11 \mathrm{~N}^{\circ}$ 29, 2020

Vladimir Nikolaevich Aniskin, et al./// Teaching potential of integrated learning... 328-336

Habib-Mireles, L.; Zambrano, G.; Hernández, M. (2015). Eficacia de un programa internacional para mejorar el rendimiento académico en Ingeniería, Revista de la Universidad del Zulia, 6 (14), 67-86.

Idrisov, G.I., Knyaginin, V.N., Kudrin, A. L., \& Rozhkova, E. S. (2018). New technological revolution: challenges and opportunities for Russia. Economic Issues, 4 , $5-25$.

Ivinskaya M. S. (2017). Improving the quality of education based on use of the electronic information and educational environment. Azimuth of Scientific Research: Pedagogy and Psychology. T. 6. No. 1 (18). S. 73-75.

Klemasheva E.I. (2018). The tools of reproduction and stimulation of the engagement of human capital in the new industrialization. Azimuth of Scientific Research: Economics and Administration. T. 7. No. 3 (24). S. 116-119.

Krasilnikova, V.A. (2012). The use of information and communication technologies in education: textbook. manual for universities.

Mahotin, D.A. (2018). SMART in education: a new approach or the impact of technology ?. Interactive Education, (5), 13-15.

Matveeva A.V., Krotova E.A. (2017). Applying of the opportunities of the electronic educational environment in ecological education. Karelian Scientific Journal. T. 6. No. 2 (19). S. 26-28.

Nakashima, H., Aghajan, H., \& Augusto, J. C. (Eds.). (2009). Handbook of ambient intelligence and smart environments. Springer Science \& Business Media.

Prigogine, A.I. (2003). Organization development methods.

Sharipov, F. F., \& Source, R. S. I. I. A. R. of operational and objective educational information Azimuth of scientific research: pedagogy and psychology. 2017. T. 6. No. 2 (19). S. 188, 191.

Shubina, I.V. (2015). Smart and the development of modern education. Eurasian Union of Scientists, (3-1 (12)).

Timofeev, A.G., Lebedinskaya, O.G., \& Bilenko, A.V. (2019). Digital economy: realities, prospects and development priorities. Greater Eurasia: Development, Security, Cooperation, (2-1).

Vanyukova, A.A. (2018). Professional competence of an additional education teacher in organizing research activities of students in the system of additional education. Scientific and practical education, research training, STEAM education: new types of educational situations (pp. 190-195).

Zavrazhin, A. V. (2015). Smart and humanitarian aspects of teaching in high school. Statistics and Economics, (3). 